TITLE:

Calanoid Copepods Collected from the Near-bottom in Tanabe Bay on the Pacific Coast of the Middle Honshu, Japan. IV. Pseudocyclopiidae

$\operatorname{AUTHOR}(\mathrm{S})$ :

Ohtsuka, Susumu

CITATION:

Ohtsuka, Susumu. Calanoid Copepods Collected from the Near-bottom in Tanabe Bay on the Pacific Coast of the Middle Honshu, Japan. IV. Pseudocyclopiidae. PUBLICATIONS OF THE SETO MARINE BIOLOGICAL LABORATORY 1992, 35(4-5): 295-301

ISSUE DATE:

1992-03-31

URL:

http://hdl.handle.net/2433/176199

RIGHT: 


\title{
Calanoid Copepods Collected from the Near-bottom in Tanabe Bay on the Pacific Coast of the Middle Honshu, Japan. IV. Pseudocyclopiidae
}

\author{
Susumu Ohtsuka \\ Faculty of Applied Biological Science, Hiroshima University \\ 4-4, Kagamiyama 1-chome, Higashi-Hiroshima 724, Japan
}

With Text-figures $1-3$ and Table 1

\begin{abstract}
Pseudocyclopia muranoi, a new species (Copepoda: Calanoida) from shallow water on the Japanese Pacific coast is described. This is the first record of the genus in the Indo-Pacific region. This species is distinguished from congeneric species by its relatively long antennule, urosome with numerous scales, and structure of legs 4 and 5 of both sexes. The swimming behavior and gut contents of the new species were also observed.
\end{abstract}

This paper covers the description of a new species belonging to the genus Pseudocyclopia T. Scott, 1892 (family Pseudocyclopiidae) as the fourth in a series of taxonomic works on the near-bottom calanoid copepods from Tanabe Bay on the Pacific coast of Honshu, Japan. The genus has hitherto comprised only six species, all of which are known from the Atlantic Ocean: P. crassicornis Scott, 1892; P. minor Scott, 1892; P. caudata Scott, 1894; P. stephoides Thompson, 1895 (in Sars, 1903); P. giesbrechti Wolfenden, 1902 (in Sars, 1921); P. insignis Andronov, 1986. Their occurrence in the Atlantic ranges broadly from the boreal Norwegian coast to tropical Mauritania (Andronov, 1986; Fosshagen \& Iliffe, 1985; Rose, 1933; Sars, 1903, 1921; Scott, 1892). The genus seems to be distributed in near-bottom waters of continental shelves (e.g. Andronov, 1986; Sars, 1903, 1921). This is the first record of the genus from shallow water in the Indo-Pacific region.

The genus Pseudocyclopia was established by Scott (1892), but at that time the type species was not designated. Following the procedure outlined in the International Code of Zoological Nomenclature (Article 69), Pseudocyclopia crassicornis Scott, 1892 is hereby subsequently designated as its type species, because this species is more completely described compared with $P$. minor Scott, 1892, which is described in the same paper.

The present specimens were collected from the lower intertidal and subtidal zones in a small inlet facing the south side of the Seto Marine Biological Laboratory during the daytime low tide. A weighted conical net was towed along the pebbly bottom. Specimens of the new species were only captured when the net touched the bottom.

The swimming behavior of the new species was recorded with a VHS tape recorder system (Hitachi KP-C210; Victor BR-S610). Gut contents of type specimens were dissected out and examined with a differential interference microscope.

Publ. Seto Mar. Biol. Lab., 35(4/5), 295-301, 1992. （Article 11) 


\title{
Pseudocyclopia muranoi, n. sp.
}

\author{
(Figs 1-3)
}

Types. Holotype: + , dissected and mounted on glass slides (10-I-1986, less than $2 \mathrm{~m}$ in depth). Allotype: $\hat{\sigma}$, dissected and mounted on glass slides (12-V-1987, less than $2 \mathrm{~m}$ in depth). Paratypes: 2 우 \& $20 \hat{0}$, dissected and mounted on glass slides; , whole specimen (12-V-1987, less than $2 \mathrm{~m}$ in depth). All type specimens are deposited in the Seto Marine Biological Laboratory, Kyoto University.

Type locality: a small inlet, Kanayama Bay, located just south of the Seto Marine Biological Laboratory $\left(33^{\circ} 41^{\prime} \mathrm{N}, 135^{\circ} 21^{\prime} \mathrm{E}\right)$.

Female (holotype). Body (Fig. 1-A,B) $0.98 \mathrm{~mm}$ in length. Prosome, viewed dorsally, compressed on both sides. Cephalosome incompletely fused with first pedigerous segment. Rostrum (Fig. 1-D) movable; its tip slightly swollen and without filaments. Fourth and fifth pedigerous segments completely fused, lateral sides expanded posteriorly and reaching to one-third length of genital segment. Urosome (Fig. 1-G) 4-segmented; genital segment slightly asymmetrical with oval genital operculum located ventro-medially; second and third segments entirely covered with "scales" like those of Pseudocyclops lepidotus Barr \& Ohtsuka, 1989; anal segment fringed ventro-posteriorly with relatively long spinules; furcal ramus broader than long; small process located near minute ventral seta. Antennule (Fig. 1-D) reaching to midlength of first pedigerous segment; both antennules symmetrical, 24segmented, first four and 10th and 11th segments incompletely fused. Antenna (Fig. 1-E) : basipod 1 small, bearing row of fine hairs; basipod 2 more or less completely fused with endopod; endopod 2-segmented, first segment elongated, bearing four marginal setae, second segment with 13 setae terminally; exopod 6-segmented, second segment with minute medial and subterminal setae and developed terminal seta. Mandible (Fig. 1-F): gnathobase heavily chitinized; basipod with patch of minute spinules basally and three inner marginal setae of unequal lengths; endopod 2-segmented, first segment with terminal seta and second segment with 11 setae; exopod 4-segmented. Maxillule (Fig. 1-G) well developed; first to third inner lobes having 13, 2 and 4 setae, respectively; outer lobe bearing nine setae; basipod 2 incompletely fused with endopod and exopod, these rami with 11 and 8 setae, respectively. Maxilla (Fig. 2-A) with five basipodal inner lobes; first to fourth inner lobes bearing 5, 3, 3 and 3 setae, respectively; fifth inner lobe large, produced with two stout, scythe-shaped setae. Maxilliped (Fig. 2-B) elongated; basipod 1 produced terminally into knob with two setae of unequal lengths; basipod 2 with three medial and two terminal setae: endopod 5-segmented, first to fifth segments bearing 4, 4, 3, 4 and 3 setae, respectively; basipod 2 and second to fourth endopod segments each having row of spinules.

Spinulation and setation of legs shown in Table 1. Leg 1 (Fig. 2-C): basipod 2 with small outer spine at subterminal end; endopod 1-segmented, produced terminally into blunt process; proximal segment of exopod expanded along inner margin. Leg 2 (Fig. 2-D) : basipod 1 bearing large inner spine reaching to about three-fourths 


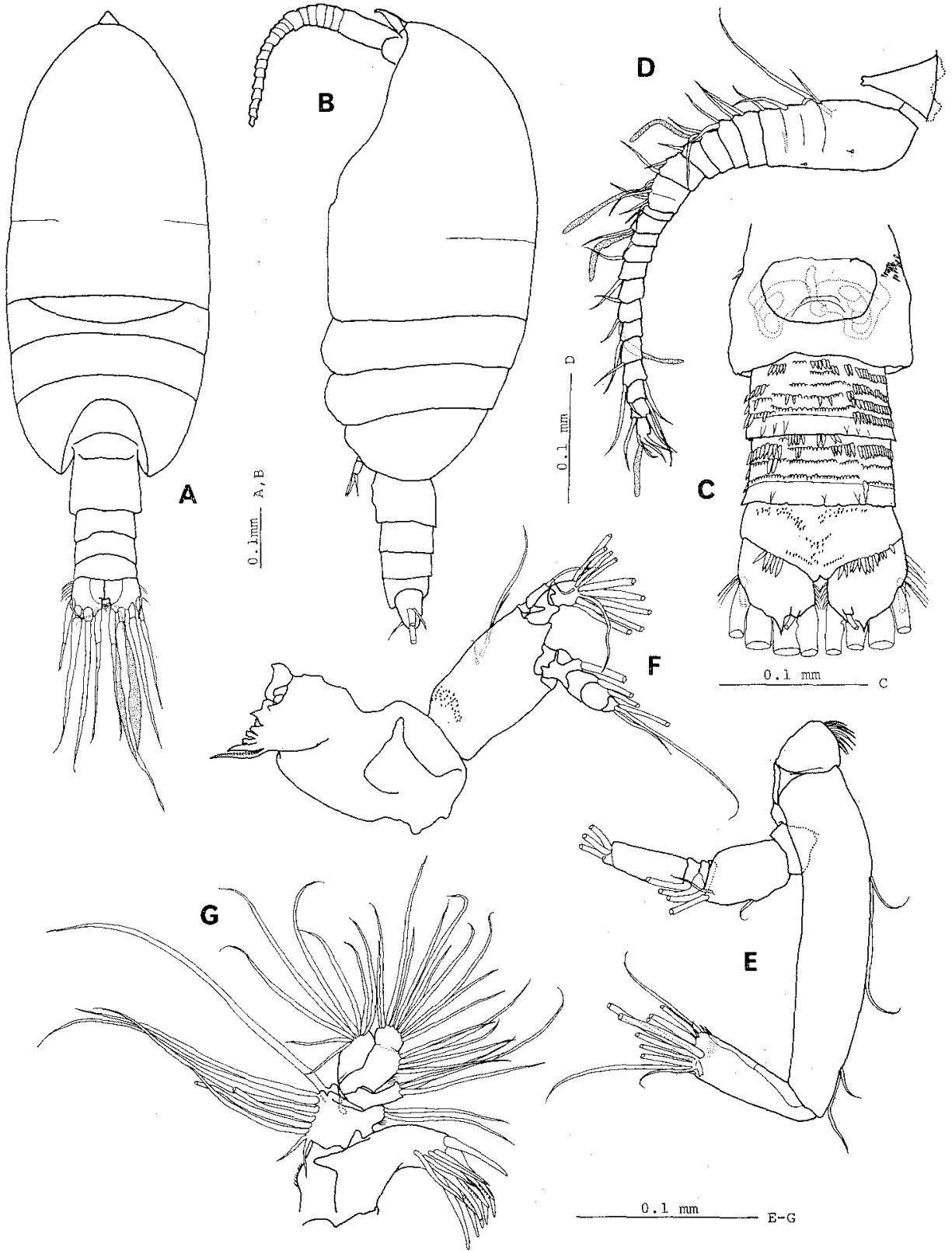

Fig. 1. Pseudocyclopia muranoi, n. sp. Female (holotype). A. Habitus, dorsal view; B. Habitus, lateral view; C. Urosome, ventral view; D. Antennule and Rostrum; E. Antenna; F. Mandible; G. Maxillule.

length of second endopod segment; endopod 2-segmented. Leg 3 (Fig. 2-E): basipod 1 with large inner spine reaching to about midlength of third endopod segment; endopod 3-segmented. Leg 4 (Fig. 2-F) : basipod 1 more elongated than those of legs 2 and 3; endopod 3-segmented, first and second segments each bearing stout; 


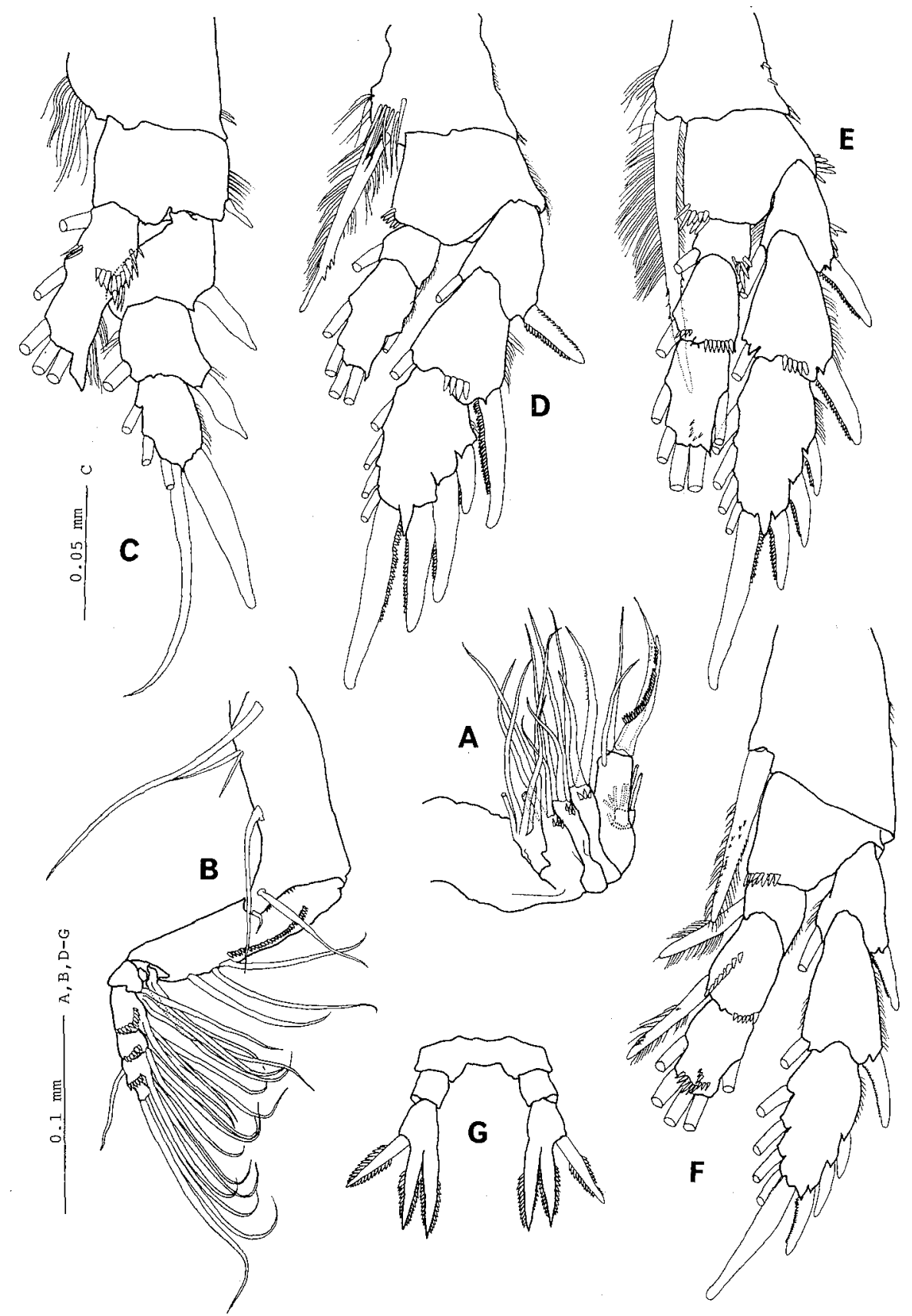

Fig. 2. Pseudocyclopia muranoi, n. sp. Female (holotype). A. Maxilla; B. Maxilliped; C. Leg. 1; D. Leg 2; E. Leg 3; F. Leg 4; G. Leg 5.

short spine at inner distal end. Leg 5 (Fig. 2-G) symmetrical; both basipods 1 fused medially to form common base; basipod 2 small, unarmed; endopod absent; exopod 1-segmented, furnished with fringed outer spine and two terminal processes. 

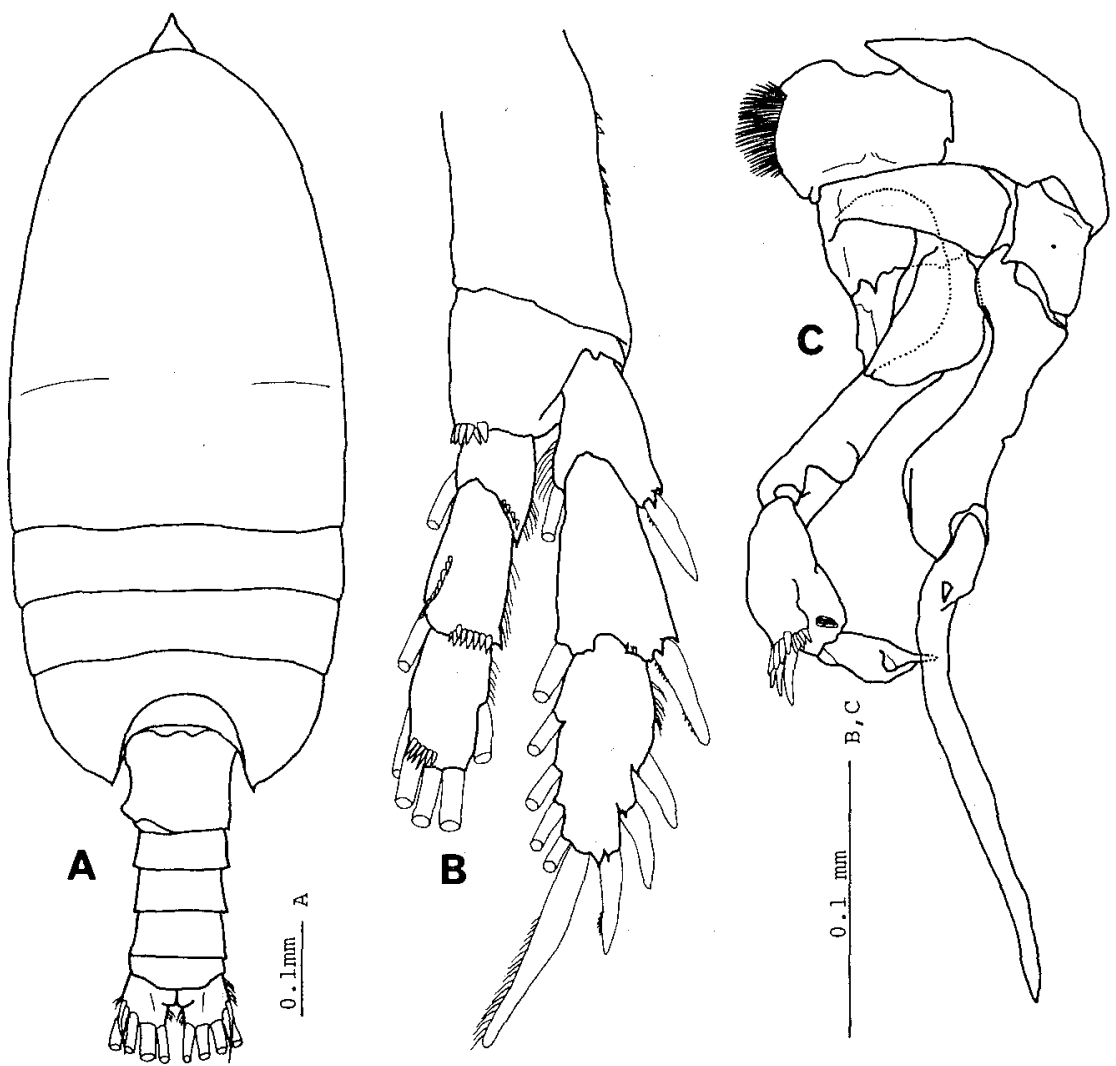

Fig. 3. Pseudocyclopia muranoi, n. sp. Male (allotype). A. Habitus, dorsal view; B. Leg 4; C. Leg 5 .

Table 1. Seta and spine formula of legs 1-4 of Pseudocyclopia muranoi, n. sp. Setae are represented by Arabic and spines by Roman numerals. $\mathrm{Si}=$ inner border of segment; $\mathrm{Se}=$ outer border of segment; $\mathrm{St}=$ terminal border of segment.

\begin{tabular}{|c|c|c|c|c|c|c|c|c|c|c|c|c|c|c|c|c|c|c|c|c|}
\hline & \multicolumn{5}{|c|}{ basipod } & \multicolumn{7}{|c|}{ endopod } & \multicolumn{8}{|c|}{ exopod } \\
\hline & \multicolumn{2}{|c|}{1} & \multicolumn{2}{|c|}{2} & \multicolumn{3}{|c|}{1} & \multicolumn{3}{|c|}{2} & \multicolumn{3}{|c|}{3} & \multicolumn{2}{|r|}{1} & \multicolumn{3}{|c|}{2} & \multicolumn{2}{|l|}{3} \\
\hline & $\mathrm{Si}$ & $\mathrm{Se}$ & $\mathrm{Si}$ & $\mathrm{Se}$ & $\mathrm{Si}$ & St & $\mathrm{Se}$ & $\mathrm{Si}$ & $\mathrm{St}$ & $\mathrm{Se}$ & $\mathrm{Si}$ & St & $\mathrm{Se}$ & $\mathrm{Si}$ & $\mathrm{Se}$ & $\mathrm{Si}$ & Se & $\mathrm{Si}$ & $\mathrm{St}$ & $\mathrm{Se}$ \\
\hline Leg 1 & 0 & 0 & 0 & I & 3 & 2 & 0 & - & - & - & - & - & - & 0 & I & 1 & I & 3 & 1 & $\mathrm{I}$ \\
\hline Leg 2 & $\mathrm{I}$ & 0 & 0 & 0 & 1 & - & 0 & 2 & 2 & 1 & - & - & - & 1 & I & 1 & I & 4 & $I$ & III \\
\hline Leg 3 & I & 0 & 0 & 0 & 1 & - & 0 & 1 & - & 0 & 2 & 2 & 1 & 1 & I & 1 & I & 4 & I & III \\
\hline Leg 4 (우) & I & 0 & 0 & 0 & I & - & 0 & I & - & 0 & 2 & 2 & 1 & 1 & I & 1 & I & 4 & I & III \\
\hline$\left(\sigma^{3}\right)$ & 0 & 0 & 0 & 0 & 1 & - & 0 & 1 & - & 0 & 2 & 2 & 1 & 1 & I & 1 & I & 4 & I & III \\
\hline
\end{tabular}

Male (allotype). Body (Fig. 3-A) $1.05 \mathrm{~mm}$ long. Urosome 5-segmented; genital segment asymmetrical and expanded postero-laterally on left side. Rostrum, mouthparts and legs 1-3 similar to counterparts of female. Leg 4 (Fig. 3-B) with following differences from that of female: basipod 1 devoid of armature; first and 
second endopod segments both lacking stout inner spines, each bearing plumose inner seta instead. Leg 5 (Fig. 3-C) uniramous; right and left basipods 1 fused, bearing row of long hairs along left outer margin. Right leg: basipod 2 expanded; exopod 3-segmented; first segment small, unarmed; second segment elongated, its medial part constricted; third segment slender, tapering distally, and having minute basal prominence. Left leg: basipod 2 wide, forming an outer pocket together with hollow outer basal part of proximal exopod segment; exopod 3 segmented, first segment elongated, second segment bearing transverse row of thick, short spinules and patch of granules near distal end, and third segment small, with two processes of unequal lengths terminally.

Etymology. The specific name "muranoi" honors Professor M. Murano of the Tokyo University of Fisheries.

Remarks. The female of Pseudocyclopia muranoi is similar to those of P. crassicornis, $P$. giesbrechti and $P$. stephoides, but distinguishable from these three species by the relatively long antennule, the urosome with scales, the presence of a small spine near the outer distal end of basipod 2 of leg 1 and a long spine at the inner distal end of basipod 1 of $\operatorname{leg} 4$, and the structure of leg 5 .

The male of $P$. muranoi closely resembles that of $P$. stephoides, but differs from it in the structure of leg 5 : basipod 1 bearing row of long hairs along left outer margin; third exopod segment of the right leg less than twice as long as the second one; the second exopod segment of the left leg not as elongate as that of $P$. stephoides, without outer setae and lamellar distal lobes.

In this new species, sexual dimorphism is observed in leg 4 in addition to its usual occurrence in the leg 5 and the urosome. Only the female has long, thick inner spines on the basipod 1 and the first and second endopod segments of leg 4. Such sexual dimorphism is also described in P. stephoides by Andronov (1986). These inner spines of the female together with leg 5 may play a role in scraping away empty spermatophores attached to the gential segment.

\section{Swimming behavior}

Among near-bottom calanoid copepods, the genera whose swimming behavior has been observed are Paracyclopia Fosshagen, 1985 (Fosshagen \& Iliffe, 1985), Paramisophria Scott, 1897 (Fosshagen, 1968; Ohtsuka \& Mitsuzumi, 1990), Ridgewayia Thompson \& Scott, 1903 (Humes \& Smith, 1974) and Stephos Scott, 1892 (Ohtsuka \& Hiromi, 1987): both Paramisophria and Stephos peculiarly swim with their left sides along the bottom. In contrast to these genera, Pseudocyclopia swam continuously and rapidly with its ventral side along the bottom, beating its antennae, mandibular palps and, probably, the outer lobes and exo- and endopods of the maxillules. Both antennules during swimming were outstretched laterally. The copepods swam just on the bottom without touching it. When the swimming direction was changed, the urosome bent toward the new direction. 


\section{Gut contents}

Gut content analysis of Pseudocyclopia muranoi revealed that this species grazed mainly on epibenthic pennate diatoms. Other food items were crustacean fragments, naked ciliates, tintinnids, cysts, pollen and unidentified remains. The in-situ feeding habit of this species resembles that of another near-bottom calanoid copepod, Stephos pacificus Ohtsuka \& Hiromi, which was found feeding primarily on hypotrichid ciliates and diatoms (Ohtsuka \& Hiromi, 1987).

\section{Acknowledgments}

I express my sincere thanks to Dr. A. Fosshagen of the University of Bergen for his critical reading of the manuscript. I am thankful to Dr. G.D. Gabriel of Hiroshima University for his translation of Andronov's (1986) Russian paper into English. Thanks are due to Professor E. Harada and the late Dr. T. Itô of Kyoto University for their kind suggestion for the deposition of the type specimens. This study was partly supported by grants of the Research Institute of Marine Invertebrates and the Nissan Science Foundation.

\section{References}

Andronov, V.N. 1986. Bottom Copepoda in the area of Cape Blanc (Islamic Republic of Mauritania) 2. The family Pseudocyclopiidae. Zool. Zh., 65: 295-298. (In Russian with English summary).

Barr, D.J. \& S. Ohtsuka. 1989. Pseudocyclops lepidotus, a new species of demersal copepod (Calanoida; Pseudocyclopidae) from the northwestern Pacific. Proc. Biol. Soc. Wash., 102: 331-338.

Fosshagen, A. 1968. Marine bioligical investigations in the Bahamas. 8. Bottom-living Arietellidae (Copepoda, Calanoida) from the Bahamas with remarks on Paramisophria cluthae T. Scott. Sarsia, 35: 57-64.

___ \& T.M. Iliffe. 1985. Two new genera of Calanoida and a new order of Copepoda, Platycopioida, from marine caves on Bermuda. Sarsia, 70: 345-358.

Humes, A.G. \& W.L. Smith. 1974. Ridgereayia fosshageni n. sp. (Copepoda; Calanoida) associated with an actiniarian in Panama, with observations on the nature of the association. Carib. J. Sci., 14: $125-139$.

Ohtsuka, S. \& J. Hiromi. 1987. Calanoid copepods collected from the near-bottom in Tanabe Bay on the Pacific coast of the middle Honshu, Japan. III. Stephidae. Publ. Seto Mar. Biol. Lab., 32: 219-232.

\& C. Mitsuzumi. 1990. A new asymmetrical near-bottom calanoid copepod, Paramisophria platysoma, with observations of its integumental organs, behavior and in-situ feeding habit. Bull. Plankton Soc. Japan, 36: 87-101.

Rose, M. 1933. Copépodes Pélagiques. Faune de France, 26: 1-374.

Sars, G.O. 1903. Copepoda. Calanoida. An account of the Crustacea of Norway, IV, Bergen Museum, Bergen. 171 pp., 108 pls.

. 1921. Copepoda. Supplement. An account of the Crustacea of Norway, VII, Bergen Museum, Bergen. 121 pp., 76 pls.

Scott, T. 1892. Additions to the fauna of the Firth of Forth. Part IV. Rep. Fishery Bd. Scotl., 10: 244-272. 